\title{
DEVELOPING INTEGRATIVE THEMATIC MATERIALS BASED ON LOCAL WISDOM ON SCIENCE SUBJECT OF THEME 3, HEALTHY FOOD, AT GRADE V
}

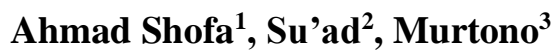 \\ ${ }^{1}$ SD Negeri 2 Purwogondo, Jepara, Indonesia \\ 2,3 Universitas Muria Kudus, Kudus, Indonesia \\ 1ahmadshofa74@gmail.com, ${ }^{2}$ suad@umk.ac.id, ${ }^{3}$ murtono@umk.ac.id
}

\begin{abstract}
The objectives of this study were 1) to analyze teachers' input to develop Integrated Thematic Materials Based on Local Wisdom on Science subject Theme 3: Healthy Food, for Grade 5 Elementary School, 2) to find out how to prepare Integrated Thematic Materials Based on Local Wisdom for Science subject Theme 3: Healthy Food, for Grade 5 Elementary School, and 3) to reveal the effectiveness of the Integrated Thematic Materials Based on Local Wisdom on Science Subject Theme 3: Healthy Food, for Grade 5 Elementary School. This research was Research and Development (R \& D) adapted from Sugiyono including ten steps. The validation of teaching materials wascarried out by proficient material experts and media experts. The results showed that the products in this development research were declared feasible and effective to be used as supporting teaching materials for grade $V$. The feasibility of this thematic module product was based on the validation results of material experts which obtained a total score of 73 in very good category and the results of validation by media experts which obtained a total score of 116 in very good category. The feasibility of the thematic module product was also strengthened by the results of the effectiveness test (N-Gain) on the product trial which obtained a score of 85.2968 or $85.30 \%$ in effective category for the experimental class, and the effectiveness test ( $N$-Gain) on the trial which obtained a score of 88,5386 or $88.54 \%$ with the effective category.
\end{abstract}

Keywords: integrated thematic materials, grade $\mathrm{V}$, local wisdom

\section{PENGEMBANGAN BAHAN AJAR TEMATIK INTEGRATIF BERBASIS KEARIFAN LOKAL MATERI IPA TEMA 3: MAKANAN SEHAT PADA SISWA KELAS 5 SEKOLAH DASAR}

\begin{abstract}
ABSTRAK
Tujuan penelitian ini adalah 1) menganalisis masukan guru untuk mengembangkan Bahan Ajar Tematik Terintegratif Berbasis Kearifan Lokal Materi IPA Tema 3: Makanan Sehat Pada Siswa Kelas 5 Sekolah Dasar, 2) mengetahui bagaimana menyusun Bahan Ajar Tematik Terintegratif Berbasis Kearifan Lokal Materi IPA Tema 3: Makanan Sehat Pada Siswa Kelas 5 Sekolah Dasar, dan 3) mengetahui efektifitas penyusunan Bahan Ajar Tematik Terintegratif Berbasis Kearifan Lokal Materi IPA Tema 3: Makanan Sehat Pada Siswa Kelas 5 Sekolah Dasar. Penelitian ini merupakan jenis Penelitian dan Pengembangan (Research and Development/R\&D) dari Prof. Dr. Sugiyono yang meliputi sepuluh langkah. Validasi bahan ajar dilakukan oleh ahli materi dan ahli media yang benar-benar mahir. Hasil penelitian menunjukkan bahwa produk yang dihasilkan dalam penelitian pengembangan ini dinyatakan layak dan efektif digunakan sebagai penunjang bahan ajar untuk kelas V. Kelayakan produk modul tematik ini didasarkan pada hasil validasi ahli materi yang memperoleh jumlah skor 73 dengan kategori sangat baik dan hasil validasi ahli media yang memperoleh jumlah skor 116 dengan kategori sangat baik. Kelayakan produk modul tematik juga diperkuat dengan hasil uji efektifitas pada ujicoba produk yang memperoleh N-Gain score kelas eksperimen sebesar 85.2968 atau $85.30 \%$ dengan kategori efektif, uji efektifitas pada ujicoba pemakaian yang memperoleh N-Gain score kelas eksperimen sebesar 88.5386 atau $88.54 \%$ dengan kategori efektif.
\end{abstract}

Kata Kunci: bahan ajar tematik integrasi, bahan ajar kelas V, kearifan lokal

\begin{tabular}{|c|c|c|}
\hline Submitted & Accepted & Published \\
\hline 06 Oktober 2020 & 05 September 2021 & 16 September 2021 \\
\hline
\end{tabular}

\begin{tabular}{|l|c|c|}
\hline Citation & $:$ & $\begin{array}{r}\text { Shofa, A., Su'ad, S., \& Murtono, M. (2021). Developing Integrative Thematic Materials Based on Local Wisdom on } \\
\text { Science Subject of Theme 3, Healthy Food, at Grade V. Jurnal PAJAR (Pendidikan dan Pengajaran), 5(5), } \\
\text { 1386-1396. DOI : http://dx.doi.org/10.33578/pjr.v5i5.8171. }\end{array}$ \\
\hline
\end{tabular}

\section{PENDAHULUAN}

Pendidikan merupakan kebutuhan dasar manusia dalam menghadapi terus berkembangnya arus globalisasi. Berbicara mengenai pendidikan

tidak dapat dipisahkan dari kurikulum yang merupakan salah satu unsur utama sumber acuan pendidikan yang dapat memberikan bukti secara 
signifikan untuk mewujudkan potensi peserta didik (Judiani 2010). Menurut Peraturan Pemerintah RI No. 19 Tahun 2005 pasal 1 tentang Standar Nasional Pendidikan disebutkan bahwa kurikulum adalah seperangkat rencana dan pengaturan mengenai tujuan, isi, dan bahan pelajaran, serta cara digunakan sebagai pedoman penyelenggaraan kegiatan pembelajaran untuk mencapai tujuan pendidikan tertentu. Pendapat senada juga diungkapkan oleh (Dimyati 2019) kurikulum merupakan satu rancangan untuk menyediakan seperangkat kesempatan belajar agar mencapai tujuan. Berdasarkan pendapat di atas, terdapat dua dimensi kurikulum yaitu seperangkat rencana dan pengaturan dalam penyelenggaraan pembelajaran untuk suatu tujuan, sehingga seorang guru sebagai tenaga pendidik wajib memfasilitasi semua aktifitas belajar peserta didik secara maksimal (Ichsan 2016).

Kurikulum 2013 menggunakan model pelaksanaan pembelajaran di sekolah dasar berbasis tematik terintegrasi. Menurut (Mulyoto 2013) pembelajaran tematik terintegrasi adalah pembelajaran yang mengintegrasikan materi beberapa mata pelajaran dalam satu tema pembahasan. Berdasarkan pengertian di atas telah mencerminkan karakteristik peserta didik kelas dua yang berada dalam rentangan usia dini yang masih memandang segala sesuatu dalam satu kesatuan yang utuh (holistik) sehingga pembelajarannya masih tergantung pada objekobjek kongkrit dan pengalaman yang dialaminya. Pengembangan kurikulum 2013 menekankan pada berbagai kompetensi guru yaitu kompetensi pedagogis, kepribadian, sosial, dan profesional. Dari kompetensi-kompetensi tersebut di atas maka guru dituntut mampu menjadi tenaga pendidik yang kreatif dalam menyusun bahan ajar yang inovatif (Suhandani and Julia 2014).

Berdasarkan observasi dan wawancara guru di Sekolah Dasar menunjukan bahwa adanya keterbatasan bahan ajar dan dalam kenyataan di lapangan masih banyak guru yang belum bisa mengembangkan bahkan menyusun bahan ajar yang sesuai dengan kondisi peserta didik. Hasil observasi juga menunjukkan kurangnya wawasan siswa mengenai lingkungan sekitar juga membuat kendala dalam proses KBM terutama yang berkaitan dengan produk-produk kearifaan lokal seperti makanan asal dan tradisi yang berkembang asal daerahnya. Paradigma dan persepsi umum yang melekat di kalangan para pendidik adalah membuat bahan ajar merupakan pekerjaan yang sulit dan membuat stres (Prastowo 2013). Para pendidik masih kurang mengembangkan kreativitas mereka untuk merencanakan, menyiapkan dan membuat bahan ajar secara matang yang dapat menarik perhatian peserta didik serta menjadikan peserta didik merasa tertantang. Para pendidik pada umumnya hanya menyediakan bahan ajar yang monoton, menggunakan bahan ajar yang telah tersedia tanpa harus bersusah payah membuatnya.

Dalam rangka mengimplementasikan kurikulum 2013, bahan ajar tematik terintegrasi yang tepat dengan dilengkapi penanaman nilainilai karakter yang berkualitas, harus terealisasikan jika menginginkan keberhasilan bangsa.

\section{KAJIAN TEORETIS}

\section{Pengertian Bahan Ajar}

Bahan ajar adalah segala bentuk bahan yang disusun secara sistematis yang memungkinkan siswa dapat belajar dengan dirancang sesuai kurikulum yang berlaku. Berdasarkan pengertian di atas bahan ajar harus dikemas sedemikian rupa dan disesuaikan dengan roh kurikulum yang berlaku sekarang (dalam hal ini yaitu kurikulum 2013) sehingga peserta didik memperoleh kemudahan dalam belajar dari berbagai bahan pelajaran (Lestari 2013).

Bahan ajar adalah segala bentuk bahan yang digunakan untuk membantu guru/instruktur dalam melaksanakan kegiatan belajar mengajar di kelas. Berdasarkan pendapat di atas, bahan ajar yang digunakan oleh para pendidik dalam melaksanakan kegiatan pembelajaran sangat bervariasi bentuknya. Bentuk bahan ajar yang 
dapat digunakan tidak hanya berbentuk buku, majalah, foto, diagram, film dan lain sebagainya (Mudlofir 2011).

Bahan ajar adalah bahan jadi yang merupakan hasil ramuan dari bahan-bahan yang diperoleh dari berbagai sumber. Berdasarkan pendapat di atas bahan ajar merupakan suatu bahan yang digunakan dalam pembelajaran dimana bahan ajar tersebut tidak hanya dari buku saja melainkan dari berbagai sumber belajar yang lainnya (Prastowo 2013).

Bahan ajar adalah bahan atau material atau sumber belajar yang mengandung substansi kemampuan tertentu yang akan dicapai oleh siswa. Berdasarkan pendapat di atas bahan ajar memiliki peran yang sangat penting bagi peserta didik dalam upaya pencapaian pemahaman suatu materi pelajaran yang harus dikuasainya (Trianto 2011).

Berdasarkan berbagai pendapat di atas mengenai pengertian bahan ajar dapat disimpulkan bahwa bahan ajar adalah segala bentuk bahan berisi materi yang disusun secara sistematis dimana bahan-bahan ajar tersebut secara garis besar terdiri dari tiga ranah yang harus dikuasai oleh peserta didik dalam rangka mencapai kompetensi inti dan kompetensi dasar yang telah ditentukan. Tiga ranah tersebut yaitu ranah kognitif (pengetahuan), afektif (sikap), dan spikomotorik (keterampilan). Bahan ajar yang digunakan oleh para pendidik diperoleh dari berbagai sumber belajar yang dapat dijadikan sebagai alat bantu pembelajaran.

\section{Jenis Bahan Ajar}

Para pendidik menggunakan beragam jenis bahan ajar untuk membantu kegiatan pembelajarannya di kelas baik bahan ajar cetak maupun bahan ajar noncetak. Dimana dari keduanya memiliki beragam bentuk masingmasing yang sama-sama memiliki manfaat penting dalam usaha kelancaran aktivitas pembelajaran di kelas.

Bahan ajar cetak merupakan berbagai informasi sebagai materi pembelajaran yang disimpan dalam berbagai bentuk tercetak, seperti buku, majalah, koran, jurnal penelitian, dan sebagainya. Sedangkan bahan ajar non cetak adalah informasi sebagai materi pembelajaran yang tersimpan dalam berbagai bentuk alat komunikasi elektronik yang biasanya digunakan sebagai media pembelajaran, seperti kaset, video, $\mathrm{CD}$, computer, dan lain sebagainya. Berdasarkan pendapat di atas dapat disimpulkan bahwa jenis bahan ajar yang dijadikan sebagai sumber pembelajaran sebagai upaya pencapaian kompetensi dasar yang telah ditentukan banyak sekali macamnya baik itu yang berbentuk cetak (visual) ataupun bahan ajar yang berbentuk noncetak (audio, audiovisual, dan interaktif) (Wiyani 2013).

Bahan ajar cetak ataupun noncetak setidaknya dapat dijadikan sebagai empat materi pembelajaran yaitu materi fakta, konsep, prinsip, dan prosedur. Secara lebih rinci uraian mengenai materi fakta, konsep, prinsip, dan prosedur dapat dijelaskan sebagai berikut (Trianto 2011).

a. Materi fakta

Materi pembelajaran termasuk kategori fakta jika menunjukkan suatu nama, objek, atau peristiwa yang terjadi secara nyata pada suatu daerah atau tempat tertentu.

\section{b. Materi konsep}

Konsep adalah materi pembelajaran dalam bentuk definisi/batasan atau pengertian dari suatu objek, baik yang bersifat abstrak maupun konkret. c. Materi prinsip

Prinsip adalah dasar atau asas yang menunjukkan hubungan antara berbagai konsep yang telah teruji kebenarannya sehingga berlaku di mana saja dan kapan saja.

d. Materi prosedur

Prosedur adalah tahapan atau langkahlangkah untuk menyelesaikan kegiatan atau aktivitas tertentu atau secara singkat sering juga disebut tatacara.

Berdasarkan uraian di atas dapat disimpulkan bahwa materi fakta yaitu materi pembelajaran yang dapat diraba dan dilihat sesuai dengan kejadian, peristiwa, atau kenyataan yang sebenarnya. Materi konsep merupakan materi 
pengetahuan yang berkaitan dengan pengertian, devinisi, ciri-ciri dan sebagainya. Materi prinsip maksudnya bahwa materi tersebut berhubungan dengan hal yang utama berkaitan dengan hubungan konsep yang satu dengan yang lainnya. Sedangkan maksud dari pengertian materi prosedur di atas yaitu mater yang berupa langkah-langkah, tahapan, dan proses.

\section{Pengertian Bahan Ajar Cetak Modul}

Modul sebagai salah satu kategori bahan ajar cetak yang memiliki karakteristik yakni terdiri dari bermacam-macam bahan tertulis yang digunakan untuk belajar mandiri (Belawati 2013). Hal senada juga diungkapkan (Prastowo 2013) bahwa modul adalah sebuah bahan ajar yang disusun secara sistematis dengan bahasa yang mudah dipahami oleh siswa, serta sesuai dengan tingkat pengetahuan dan usia siswa agar siswa dapat belajar sendiri (mandiri) dengan bantuan atau bimbingan yang minimal dari pendidik.

Sementara itu, menurut (Sukiman 2012) menjelaskan "...module as a self-contined, independent unit of a planned series of learning activities designed to help the student accomplish certain well defined"..., yang mengandung arti bahwa modul merupakan serangkaian unit kegiatan belajar mandiri yang terencana, dirancang untuk membantu siswa dalam mencapai tujuan pembelajaran tertentu.

Mengacu pada beberapa pendapat di atas, dapat dipahami bahwa modul adalah seperangkat bahan ajar cetak berupa unit-unit kegiatan pembelajaran yang disusun dan dikemas secara sistematis dan terencana untuk membantu siswa agar dapat belajar mandiri, baik secara perorangan atau sekelompok orang tanpa atau dengan bimbingan minimal dari pendidik.

Uraian definisi modul pembelajaran tersebut, akan dijadikan landasan bagi peneliti dalam mengartikan Modul Tematik secara definitif.

Berdasarkan definisi modul pembelajaran yang telah dipaparkan di atas, peneliti menyimpulkan bahwa secara definitif Modul
Tematik dapat diartikan sebagai bahan ajar cetak berupa seperangkat bahan ajar yang terdiri dari serangkaian unit kegiatan belajar yang disusun secara sistematis, menyajikan materi bahasan dari berbagai bidang studi secara tematik dan terintegrasi antara mata pelajaran satu dengan mata pelajaran lain melalui penggunaan tema yang kontekstual.

\section{Karakteristik Modul}

Modul sebagai bahan ajar cetak mempunyai karakteristik atau ciri khas yang membedakannya dengan bahan ajar cetak lainnya. Ada dua karakteristik yang dimiliki modul pembelajaran yang juga dimiliki oleh Modul Tematik, antara lain:

\section{a. Karakteristik Media Cetak}

Menurut (Daryanto 2013) dan (Belawati 2013) media cetak memiliki beberapa karakteristik berikut:

1. Penyajian dalam bentuk bahan cetakan (kertas)

2. Pemaparan informasi bersifat linear

3. Merupakan media dua dimensi dan media visual diam

4. Bersifat self sufficient dan portable

5. Tidak memerlukan keahlian khusus dalam penggunaannya

\section{b. Karakteristik Modul Pembelajaran}

Dalam Pengembangan

Media

Pembelajaran dipaparkan beberapa karakteristik modul, diantaranya (Sukiman 2012) :

\section{Self Instructional}

Media modul sebagai bahan ajar cetak memiliki sifat self instructional, dimana dalam penggunaannya siswa mampu belajar secara mandiri dan tidak tergantung pada pihak lain. Untuk memenuhi karakter self instructional, sebuah modul pembelajaran harus: a) Merumuskan kompetensi dasar yang jelas; b) Mengemas materi pembelajaran ke dalam unit-unit yang spesifik, sehingga memudahkan siswa dalam belajar; c) Menyediakan contoh dan ilustrasi pendukung kejelasan pemaparan materi pembelajaran; d) Menyajikan soal-soal 
latihan, tugas dan sejenisnya yang memungkinkan siswa untuk mengukur penguasaannya; e) Kontekstual, materi yang disajikan terkait dengan suasana atau konteks lingkungan siswa; f) Menggunakan bahasa yang sederhana dan komunikatif; g) Menyajikan rangkuman materi pembelajaran; h) Menyajikan instrumen penilaian yang memungkinkan siswa melakukan self assessment.

\section{Self Contained}

Modul memiliki karakteristik self contained jika seluruh materi pembelajaran dari satu unit kompetensi/sub kompetensi yang dipelajari terdapat dalam satu modul. Materi yang terdapat dalam modul dikemas dan dikaji dalam satu kesatuan yang utuh. Tujuannya adalah untuk memberikan kesempatan peserta didik mempelajari materi pembelajaran secara utuh.

\section{Stand Alone}

Modul memiliki karakteristik stand alone, dimana modul tidak tergantung atau tidak harus digunakan bersama-sama dengan media/bahan ajar lain. Dengan kata lain, dalam penggunaannya peserta didik tidak harus memakai media atau bahan ajar lain untuk mempelajari materi yang terdapat dalam modul. Jika pengguna atau peserta didik masih memakai bahan ajar lain selain modul yang digunakan, maka modul tersebut tidak memiliki karakteristik berdiri sendiri (stand alone).

\section{Adaptive (kontekstual)}

Modul hendaknya memiliki daya adaptif yang tinggi terhadap perkembangan ilmu pengetahuan dan teknologi. Dengan memperhatikan perkembangan ilmu pengetahuan dan teknologi, maka modul yang dikembangkan akan tetap ut to date (Sukiman 2012).

\section{User Friendly}

Karakteristik user friendly pada modul mengandung arti bahwa modul mudah digunakan oleh peserta didik atau pengguna. Setiap informasi atau materi pembelajaran yang dipaparkan dalam modul bersifat membantu dan mempermudah pengguna. Penggunaan bahasa yang sederhana, mudah dipahami, sesuai dengan sasaran pengguna merupakan salah satu bentuk user friendly.

\section{METODE PENELITIAN}

Penelitian ini merupakan penelitian yang menggunakan metode Penelitian dan Pengembangan (Research and Development/ R\&D). Metode Penelitian dan Pengembangan atau dalam bahasa inggrisnya Research and Development adalah metode penelitian yang digunakan untuk menghasilkan produk tertentu, dan menguji keefektifan produk tersebut (Sugiyono 2017).

Langkah-langkah penelitian R \& D terdiri dari 10 langkah sebagai berikut: (1) Potensi dan masalah, (2) Pengumpulan data, (3) Desain produk, (4) Validasi desain, (5) Revisi desain, (6) Ujicoba produk, (7) Revisi produk, (8) Ujicoba pemakaian, (9) Revisi produk, dan (10) Produksi masal (Sugiyono 2017).

Dalam penelitian yang dilakukan, peneliti menggunakan expert judgement dan uji efektifitas produk. Expert judgement dilakukan oleh dua subyek penelitian yaitu ahli materi tematik terintegrasi dan ahli media penyusunan bahan ajar. Dimana subyek disini bertugas untuk melakukan evaluasi serta validasi terhadap produk hasil penelitian ini yaitu modul bahan ajar tematik terintegratif berbasis kearifan lokal materi IPA tema 3: makanan sehat pada siswa kelas 5 sekolah dasar. Uji efektifitas produk dilakukan dengan cara menghitung menggunakan rumus N-gain.

Pengumpulan data dalam penelitian ini adalah pengumpulan data kualitatif dan kuantitatif. Data kualitatif yaitu data yang dihasilkan berupa kritik dan saran dari ahli materi yang nantinya akan dijadikan sebagai perbaikan. Sedangkan data kuantitatif yaitu data yang dikumpulkan berdasarkan penilaian ahli terhadap tingkat kelayakan organisasi bahan ajar yang dihasilkan.

Dalam penyusunan bahan ajar tematik terintegratif berbasis kearifan lokal materi IPA 
tema 3: makanan sehat pada siswa kelas 5 sekolah dasar menggunakan instrumen penelitian berupa angket atau kuesioner yang akan diberikan kepada ahli.

Validasi bahan ajar dilakukan oleh para ahli yang benar-benar mahir. Validasi desain bahan ajar dilakukan dengan cara menganalisis angket penilaian ahli terkait dengan pengambilan keputusan ketetapan indikator pencapaian desain dan materi bahan ajar tematik terintegrasi, sehingga dapat diketahui kekurangan dan kelebihan yang ada.

Data yang telah diperoleh baik itu data yang dijadikan sebagai data kualitatif maupun data kuantitatif disusun secara sitematis sehingga memperoleh kesimpulan umum. Hal ini sudah jelas bahwa kedua teknik analisis data tersebut mempunyai perbedaan yang sangat menonjol jika dilihat dari bentuk penyajiannya. Analisis deskriptif kualitatif tidak menggunakan data-data statistik namun berupa kata-kata baik secara tertulis maupun lisan, sedangkan analisis deskriptis kuantitatif berbalik arah dengan analisis deskriptif kualitatif yaitu berupa angka-angka dan diprosentasikan.

Data dari kriteria kuantitatif dan kualitatif tersebut digunakan untuk menunjukkan kevalidan bahan ajar yang disusun. Bila rentangan nilai dalam prosentase pencapain tujuan mencapai nilai 67-80 dengan kata lain "Baik/Layak" atau "Sangat Baik/Sangat Layak". Maka bahan ajar yang disusun tersebut valid.

\section{HASIL DAN PEMBAHASAN}

Berdasarkan hasil wawancara, diketahui bahwa kurikulum yang diterapkan di SD Negeri 2 Purwogondo untuk kelas $\mathrm{V}$ adalah Kurikulum 2013, dimana proses pembelajaran telah menggunakan pendekatan tematik integratif. Dalam pelaksanaan pembelajaran tematik guru menggunakan beberapa sumber belajar seperti lingkungan sekolah, dan bahan ajar. Selain itu, guru dan siswa menggunakan buku pegangan tematik dan LKS sebagai bahan ajar utama. Namun, guru menilai bahwa buku pegangan tematik yang digunakan memiliki beberapa kelemahan yaitu materi dalam buku pegangan terlalu banyak dan cukup berat untuk diselesaikan dalam kurun waktu yang telah ditargetkan. Soal latihan untuk siswa juga kurang lengkap. Disamping itu, materi yang membutuhkan kegiatan praktek langsung terkadang tidak dapat terlaksana dengan baik.

Selain sumber belajar dan bahan ajar, guru juga memanfaatkan benda-benda yang ada di lingkungan sekitar sekolah sebagai media untuk mempermudah siswa dalam memahami materi pelajaran. Dari wawancara tersebut diketahui pula bahwa ada beberapa kendala yang dihadapi oleh guru dan siswa dalam pembelajaran. Kendala yang dihadapi guru antara lain keterbatasan bahan ajar dan tidak bisa mengembangkan bahan ajar secara mandiri, beban mengajar terlalu banyak, siswa kurang mendapatkan pembekalan dari rumah, siswa kurang memperhatikan saat pembelajaran berlangsung. Sedangkan kendala yang dihadapi siswa yaitu kurangnya wawasan siswa mengenai lingkungan sekitar terutama yang berkaitan dengan produk-produk kearifaan lokal seperti makanan asal dan tradisi yang berkembang asal daerahnya ketika KBM, kesulitan menyesuaikan diri dalam proses pembelajaran sehingga agak lamban dari siswa lainnya, siswa sering membawa mainan dari rumah sehingga kurang fokus pada pembelajaran, mudah terpengaruh oleh temannya untuk bermain.

Berdasarkan potensi dan masalah tersebut,
peneliti mengembangkan modul tematik
terintegratif yang dapat dijadikan solusi.
Selanjutnya peneliti melakukan tahap
pengumpulan data. Dalam pengumpulan data
peneliti melakukan tahap perencanaan penelitian,
peneliti melakukan kajian terhadap hasil penelitian
pendahuluan dengan mengidentifikasi serta
menganalisis masalah dan kebutuhan yaitu
mencari dan mengumpulkan referensi materi dari
beberapa buku pelajaran tematik yang telah sesuai
dengan Kurikulum 2013 dan mempersiapkan
peralatan dan aplikasi yang dibutuhkan dalam
pengembangan bahan ajar tematik terintegratif


berbasis kearifan lokal materi IPA tema 3: makanan sehat pada siswa kelas 5 sekolah dasar.

Dalam desain produk peneliti melakukan kegiatan: analisis, perencanaan pengembangan, dan melakukan desain. Hasil pengembangan desain produk berupa prototype Modul Tematik yang telah dicetak dan dikemas dalam bentuk buku/modul utuh, selanjutnya diserahkan kepada ahli materi dan ahli media untuk divalidasi dan dievaluasi, sehingga layak diuji-cobakan pada tahap selanjutnya. Revisi desain Modul Tematik dilakukan sesuai saran dan masukan dari ahli materi dan ahli media. Setelah melakukan revisi desain peneliti melakukan ujicoba produk.

Validasi oleh ahli materi ditujukan untuk mengetahui kualitas materi dalam Modul Tematik. Ahli materi memberikan penilaian terhadap beberapa aspek diantaranya aspek kelayakan isi, aspek kelayakan bahasa, dan aspek kelayakan penyajian. Berdasarkan data-data yang telah diperoleh dari angket penilaian ahli materi, diketahui bahwa perolehan jumlah skor nilai memperoleh 73 dengan kriteria sangat baik. Hal ini menunjukan aspek kelayakan isi menunjukkan bahwa materi Modul Tematik telah sesuai dengan tujuan pembelajaran yang ingin dicapai; aspek kelayakan bahasa menunjukan bahasa yang digunakan dalam modul sesuai dengan sasaran pengguna; aspek kelayakan penyajian menjelaskan bahwa penyajian materi dalam Modul Tematik mampu mendorong terjadinya proses belajar. Perolehan skor akhir dari ahli materi tersebut menunjukan bahwa kualitas materi dalam Modul Tematik telah layak dan dapat dipertanggungjawabkan. Hal ini dapat diartikan bahwa materi yang tertuang dalam Modul Tematik telah sesuai dengan tujuan kurikulum yang ingin dicapai. Data hasil penilaian ahli materi disajikan dalam Tabel 1.

Tabel 1. Data Hasil Penilaian Ahli Materi

\begin{tabular}{clc}
\hline No. & \multicolumn{1}{c}{ Indikator } & Skor \\
& KELAYAKAN ISI & \\
1 & Kesesuaian dengan KI, KD & 4 \\
2 & Kesesuaian dengan kebutuhan siswa & 5 \\
3 & Kesesuaian dengan kebutuhan bahan ajar & 5 \\
4 & Kebenaran substansi materi & 5 \\
5 & Manfaat untuk penambahan wawasan pengetahuan & 5 \\
6 & Kesesuaian dengan nilai-nilai, moralitas, sosial & 4 \\
7 & KEBAHASAAN & 5 \\
8 & Keterbacaan & 4 \\
9 & Kejelasan informasi & 4 \\
10 & Kesesuaian dengan kaidah Bahasa Indonesia & 4 \\
\hline
\end{tabular}


Jurnal PAJAR (Pendidikan dan Pengajaran)

Volume 5 Nomor 5 September 2021 | ISSN Cetak : 2580 - 8435 | ISSN Online : 2614 - 1337

DOI : http://dx.doi.org/10.33578/pjr.v5i5.8171

\begin{tabular}{clc}
12 & Urutan penyajian & 5 \\
13 & Pemberian motivasi & 3 \\
14 & Interaktivitas (stimulus dan respond) & 5 \\
15 & Kelengkapan informasi & 5 \\
16 & Kelengkapan Buku & 5 \\
\hline Jumlah Skor & & 73 \\
\hline Kategori & & Sangat Baik
\end{tabular}

Uji kelayakan terhadap aspek media dalam Modul Tematik, ditujukan untuk mengetahui kualitas dan kelayakan Modul Tematik sebagai penunjang bahan ajar siswa. Uji kelayakan ini dilakukan melalui validasi dan evaluasi oleh ahli media terkait aspek tampilan media, aspek kualitas grafis, dan aspek isi bahan ajar. Pada validasi ahli media tahap skor akhir ditinjau dari semua aspek tersebut adalah 116 yang termasuk dalam kategori sangat baik. Dengan demikian, dapat disimpulkan bahwa berdasarkan hasil uji kelayakan oleh ahli materi dan ahli media, maka Modul Tematik sebagai penunjang bahan ajar siswa telah memenuhi kriteria kelayakan bahan ajar menurut Badan Standar Nasional Pendidikan (BSNP 2007). Hal ini ditunjukan dengan hasil penilaian ahli terhadap aspek kelayakan materi, kelayakan kebahasaan, kelayakan penyajian dan kelayakan kegrafikan dalam Modul Tematik memperoleh kategori sangat baik. Yang mana semua aspek penilaian tersebut merupakan kriteria kelayakan bahan ajar menurut (BSNP 2007). Data hasil penilaian ahli media disajikan dalam Tabel 2.

Tabel 2. Data Hasil Penilaian Ahli Media

\begin{tabular}{llc}
\hline No. & \multicolumn{1}{c}{ Indikator } & Skor \\
\hline & TAMPILAN BAHAN AJAR (FISIK MODUL) & \\
1 & Kesesuaian ukuran bahan ajar dengan standar ISO & 4 \\
2 & Pemilihan jenis kertas & 4 \\
3 & Kualitas bahan kertas & 4 \\
4 & Kualitas cetakan & 4 \\
5 & Kemudahan dalam membawa modul & 5 \\
6 & Tingkat keamanan dalam penggunaan & 5 \\
7 & Kenyamanan dalam pemakaian & 5 \\
8 & Kemudahan dalam pemanfaatan & 4 \\
9 & Kualitas Jilidan & 4 \\
\hline & KUALITAS GRAFIS & 5 \\
10 & Tampilan bahan ajar secara keseluruhan & 5 \\
12 & Kemenarikan tampilan bahan ajar & 4 \\
13 & Proporsional layout (tata letak teks dan gambar) & 5 \\
14 & Keseimbangan warna pada tampilan & 5 \\
15 & Konsistensi desain background bahan ajar & 4 \\
16 & Konsistensi tata letak gambar pada bahan ajar & 5 \\
\hline
\end{tabular}




\begin{tabular}{llc}
\hline & ISI BAHAN AJAR & \\
17 & Keseimbangan warna & 5 \\
18 & Ketepatan pemilihan jenis huruf & 4 \\
19 & Konsistensi tata letak font & 4 \\
20 & Kesesuaian ukuran huruf yang digunakan & 5 \\
21 & Keterbacaan huruf & 4 \\
22 & Pemisah antar paragraf jelas & 4 \\
23 & Keharmonisan unsur tata letak & 4 \\
24 & Penggunaan variasi huruf tidak berlebihan & 5 \\
25 & Tipografi isi bahan ajar memudahkan pemahaman & 4 \\
26 & Kesesuaian ilustrasi/gambar dengan isi materi & 5 \\
\hline & $\quad$ Jumlah Skor & 116 \\
\hline
\end{tabular}

Uji produk dilakukan dalam kelompok kecil di 4 SD yaitu sekolah dasar kelas V. Uji coba lapangan dalam kelompok kecil dilakukan dengan mengujicobakan produk bahan ajar kepada guru dan siswa sebagai pengguna produk. Hasil uji kelompok kecil dimanfaatkan untuk merevisi produk. Uji coba kelompok kecil dan revisi produk dilakukan dengan kolaborasi antara peneliti dan guru. Uji coba kelompok kecil dilakukan sampai diperoleh produk yang lebih baik dari produk sebelumnya dan siap untuk diujikan pada uji selanjutnya. Dari analisis efektifitas ujicoba produk yang telah dilaksanakan dapat dijelaskan hasil perhitungan $\mathrm{N}$-gain score dalam bentuk persen untuk kelas kontrol dengan nilai rata-rata $39.51 \%$

Sedangkan nilai rata-rata $\mathrm{N}$-gain score kelas eksperimen sebesar 85.30. Sehingga dapat disimpulkan dari hasil perhitungan uji N-Gain score tersebut, menunjukkan bahwa nilai rata-rata $\mathrm{N}$-gain score untuk kelas eksperimen (dengan menggunakan modul Tematik Terintegratif Berbasis Kearifan Lokal Materi IPA Tema 3: Makanan Sehat Pada Siswa Kelas 5 Sekolah Dasar) adalah sebesar 85,2968 atau 85,30\% termasuk kategori Efektif. Sementara untuk ratarata $\mathrm{N}$-gain score untuk kelas kontrol eksperimen (tanpa menggunakan modul Tematik Terintegratif Berbasis Kearifan Lokal Materi IPA Tema 3: Makanan Sehat Pada Siswa Kelas 5 Sekolah Dasar) adalah sebesar 39.5080 atau $39.51 \%$ termasuk kategori Tidak efektif. Maka dapat disimpulkan bahwa penggunaan modul Tematik Terintegratif Berbasis Kearifan Lokal Materi IPA Tema 3: Makanan Sehat Pada Siswa Kelas 5 Sekolah Dasar efektif untuk meningkatkan hasil belajar siswa. Sementara penggunaan tanpa modul Tematik Terintegratif Berbasis Kearifan Lokal Materi IPA Tema 3: Makanan Sehat Pada Siswa Kelas 5 Sekolah Dasar tidak efektif untuk meningkatkan hasil belajar siswa. Pada proses uji coba lapangan awal, peneliti mengamati dan mencatat kendala apa saja yang dialami siswa saat menggunakan Modul Tematik. Kendala tersebut dijadikan acuan dalam merevisi Modul Tematik.

Ujicoba pemakaian dilakukan dalam kelompok besar sebanyak 10 SD. Uji coba lapangan dalam kelompok besar dilakukan dengan mengujicobakan produk bahan ajar kepada guru dan siswa sebagai calon pengguna produk. Hasil uji kelompok besar dimanfaatkan untuk merevisi produk. Uji coba kelompok besar dan revisi produk dilakukan dengan kolaborasi antara peneliti dan guru. Uji coba kelompok besar dilakukan sampai diperoleh produk yang lebih baik dari produk sebelumnya dan siap untuk produk masal. Pengujian dilakukan dengan ekperimen yaitu dengan menghitung efektivitas produk. Uji efektivitas produk dilakukan dengan melihat perbedaan skor prestasi siswa sebelum diberikan perlakuan dan skor prestasi siswa setelah diberikan perlakukan. Pemberian perlakuan dalam penelitian 
berupa penggunaan produk modul tematik terintegratif berbasis kearifan lokal materi IPA tema 3: makanan sehat pada siswa kelas 5 sekolah dasar. Dari hasil hasil pehitungan N-gain score dalam bentuk persen untuk kelas kontrol dengan nilai rata-rata $38.54 \%$. Sedangkan nilai rata-rata $\mathrm{N}-$ Gain score kelas eksperimen sebesar 88.54. Dengan demikian dapat disimpulkan dari hasil perhitungan uji N-Gain score tersebut, menunjukkan bahwa nilai rata-rata $\mathrm{N}$-gain score untuk kelas eksperimen (dengan menggunakan modul Tematik Integratif Berbasis Kearifan Lokal Materi IPA Tema 3: Makanan Sehat Pada Siswa Kelas 5 Sekolah Dasar) adalah sebesar 88.5386 atau $88.54 \%$ termasuk kategori Efektif. Sementara untuk rata-rata $\mathrm{N}$-gain score untuk kelas kontrol (tanpa menggunakan modul Tematik Terintegratif Berbasis Kearifan Lokal Materi IPA Tema 3: Makanan Sehat Pada Siswa Kelas 5 Sekolah Dasar) adalah sebesar 38.5434 atau $38.54 \%$ termasuk kategori Tidak efektif. Maka dapat disimpulkan bahwa penggunaan modul Tematik Integratif Berbasis Kearifan Lokal Materi IPA Tema 3: Makanan Sehat Pada Siswa Kelas 5 Sekolah Dasar efektif untuk meningkatkan hasil belajar siswa. Sementara penggunaan tanpa modul Tematik Terintegratif Berbasis Kearifan Lokal Materi IPA Tema 3: Makanan Sehat Pada Siswa Kelas 5 Sekolah Dasar tidak efektif untuk meningkatkan hasil belajar siswa.

Berdasarkan pengamatan peneliti selama proses uji coba tahap terakhir (ujicoba pemakaian), tidak ada kendala atau masalah yang ditunjukan guru dan siswa saat menggunakan Modul Tematik. Sehingga, tidak ada komponen Modul Tematik yang direvisi lagi. Kegiatan penelitian dan pengembangan Modul Tematik berdasarkan tahapan pengembangan Prof. Dr.Sugiyono selesai dilakukan. Berdasarkan hasil ujicoba produk yang telah dilakukan oleh peneliti dengan hasil produk efektif dan layak untuk diproduksi masal. Karena keterbatasan tenaga, waktu, dan biaya peneliti maka produksi produk hanya dapat diproduksi sebanyak 25.

\section{SIMPULAN DAN REKOMENDASI}

Simpulan dari penelitian ini adalah sebagai berikut. 1) Masukan guru untuk pengembangan bahan ajar tematik terintegratif kelas V tema 3 makanan sehat mata pelajaran IPA sekolah dasar berbasis kearifan lokal dalam tahap uji coba produk yaitu : kearifan lokal sebaiknya selain mengulas daerah sendiri juga diulas kearifan lokal daerah lain agar siswa memiliki wawasan yang lebih luas tentang daerahnya yang ada di sekitar dan batasi kearifan lokal seputar produk-produk kearifan lokal saja misalkan makanan khas dan tradisi masyarakat saja agar materi tidak melebar kemana-mana. Masukan guru dalam ujicoba produk telah direvisi dalam ujicoba pemakaian sehingga produk telah layak, 2) Penyusunan bahan ajar tematik terintegratif kelas $\mathrm{V}$ tema 3 makanan sehat mata pelajaran IPA sekolah dasar berbasis kearifan lokal meliputi 10 langkah yang dilakukan yaitu: 1. Potensi dan masalah, 2. Pengumpulan data, 3. Desain produk, 4. Validasi desain, 5. Revisi desain, 6. Ujicoba produk, 7. Revisi produk, 8. Ujicoba pemakaian, 9. Revisi produk, dan 10. Produksi masal, 3) Berdasarkan pembahasan hasil penelitian dan pengembangan Modul Tematik yang telah dipaparkan sebelumnya, maka dapat disimpulkan bahwa produk Modul Tematik yang dikembangkan telah efektif dan layak digunakan sebagai penunjang bahan ajar siswa kelas V. Hal ini didasarkan hasil penilaian produk Modul Tematik dari ahli materi dan ahli media, serta penilaian dari hasil ujicoba produk, ujicoba pemakaaian yang telah dipaparkan pada bab sebelumnya.

Saran dalam penelitian ini yaitu: 1) Mengingat pembelajaran tematik merupakan pembelajaran yang mengintegrasikan berbagai mata pelajaran dalam suatu tema, maka pembelajaran tematik membutuhkan penggunaan bahan ajar lebih dari satu. Oleh sebab itu, dalam melaksanakan pembelajaran tematik diharapkan guru tidak hanya menggunakan satu bahan ajar saja, tetapi lebih memvariasikan penggunaan bahan ajar agar pengetahuan siswa lebih luas dan 
berkembang. Setidaknya, guru menggunakan penunjang bahan ajar lainnya untuk menunjang bahan ajar utama, 2) Sebaiknya fasilitas pembelajaran yang ada di perpustakaan yakni bahan ajar cetak (buku pelajaran) yang kurang relevan dengan kurikulum diperbaharui, ditambah dan lebih divariasikan dengan menyesuaikan kurikulum, 3) Bagi pengembang hendaknya menyesesuaikan dengan keadaan dan kebutuhan siswa.

\section{DAFTAR PUSTAKA}

Belawati, T. (2013). Pengembangan Bahan Ajar Edisi Kesatu. Jakarta: Pusat Penerbitan Universitas Terbuka.

BSNP, Peraturan Menteri Pendidikan Nationakl R. I. (2007). "No. 41 Tahun 2007, Tentang Standar Proses Untuk Satuan Pendidikan Dasar Dan Menengah."

Daryanto. (2013). Media Pembelajaran. Yogyakarta: Gaya Media.

Dimyati. (2019). Belajar Dan Pembelajaran. Jakarta: Rineka Cipta.

Ichsan, M. (2016). "Psikologi Pendidikan Dan Ilmu Mengajar." JURNAL EDUKASI: Jurnal Bimbingan Konseling 2(1):60-76.

Judiani, S. (2010). "Implementasi Pendidikan Karakter Di Sekolah Dasar Melalui Penguatan Pelaksanaan Kurikulum." Jurnal Pendidikan Dan Kebudayaan 16(9):280-89.

Lestari, I. (2013). Pengembangan Bahan Ajar Berbasis Kompetensi. Padang: Akademia Permata.

Mudlofir, A. (2011). Aplikasi Pengembangan Kurikulum Tingkat Satuan Pendidikan Dan Bahan Ajar Dalam Pendidikan Agama Islam. Jakarta: PT Rajagrafindo Persada.

Mulyoto. (2013). Strategi Pembelajaran Di Era Kurikulum 2013. Jakarta: Prestasi Pustakaraya.

Prastowo, A. (2013). Panduan Kreatif Membuat Bahan Ajar Inovatif. Jogjakarta: DIVA Press.
Sugiyono. (2017). Metode Penelitian Pendidikan (Pendekatan Kuantitatif, Kualitatif, Dan $R \& D)$. Bandung: Alfabeta.

Suhandani, D, and Julia, J. (2014). Identifikasi Kompetensi Guru Sebagai Cerminan Profesionalisme Tenaga Pendidik Di Kabupaten Sumedang (Kajian Pada Kompetensi Pedagogik). Mimbar Sekolah Dasar 1(2):128-41.

Sukiman. (2012). Pengembangan Media Pembelajaran. Yogyakarta: PT Pustaka Insan Madani.

Trianto. (2011). Model Pembelajaran Terpadu. Jakarta: PT Bumi Aksara.

Wiyani, N. A. (2013). Desain Pembelajaran Pendidikan (Tata Rancang Menuju Pencapaian Kometensi). Yogyakarta: Ar-ruzz Media. 